\title{
INFORMAL BUSINESS TOURISM IN CAMEROON
}

\author{
Tembi Maloney TICHAAWA* \\ University of Johannesburg, School of Tourism \& Hospitality, College of Business and Economics, South Africa, e-mail: tembit@uj.ac.za
}

\begin{abstract}
Citation: Tichaawa, T.M. (2021). INFORMAL BUSINESS TOURISM IN CAMEROON. GeoJournal of Tourism and Geosites,
\end{abstract} 38(4), 1289-1298. https://doi.org/10.30892/gtg.38437-771

\begin{abstract}
The uniqueness of business tourism in the African context is argued to be an amalgam of several clusters of activities manifested in both the formal and informal sectors. In this study, business tourism in the global south, with a specific focus on the informal sector in Cameroon is analysed. Using data that was collected from a series of semi-structured interviews conducted with three hundred and seventy-seven business travellers, the study reveals that informal business tourism includes domestic business travellers classified into five distinctive categories: (1) informal salespeople (2) shopowners (3) herdsmen (4) local farmers and (5) wholesalers. The study concludes that informal business tourism represents an important sector that contributes to tourism development and if well harnessed, its multiplier effect could be widespread amongst the different economic sectors of Cameroon.
\end{abstract}

Key words: informal business tourism, Cameroon, informal business traders, domestic tourism

\section{INTRODUCTION}

Business tourism is one of the oldest forms of travel and has been acknowledged as an essential component of international tourism (Rogerson, 2015; Marques and Pinho, 2021). Indeed, pre-COVID-19, business tourism was identified as one of the largest growing segments of tourism, with the United Nations World Tourism Organisation (2017) reporting business tourism to account for $40 \%$ of the total international tourism market. Further, the World Travel and Tourism Council (WTTC) recorded that business tourism contributes to approximately $21.5 \%$ of the total tourism receipts (WTTC, 2019). Despite its prominence, business tourism has been recognized as a significantly under researched area in scholarship (Rogerson, 2015; 2014a; 2014b; Tichaawa, 2017; Spencer and Bavuma, 2018; Marais et al., 2017) with available literature on the sector within the developing context being very limited and far scarcer than for its developed counterpart.

For Sub-Saharan Africa, business tourism is of great significance as it contributes a major portion of international arrivals (Rogerson, 2015; 2014a; 2014b; Tichaawa, 2017; Spencer and Bavuma, 2018; Marais et al., 2017; Davidson, 2018). Christie et al. (2013) notably point out the uniqueness of business tourism in the developing context, averring business tourism volumes to far exceed those of leisure travel. Indeed, business tourism in the developing context has been advanced such that it has developed an additional, and crucial component - the informal sector (Rogerson, 2018, 2015; Makoni and Tichaawa, 2021). The United Nations Centre for Trade and Development (UNCTAD) (2019) defines informal business tourism as travel conducted by small, unregistered and vulnerable traders within and/or between neighbouring countries. This informal sector of business tourism has been underscored to have wide economic impacts, particularly relating to local economic development. The informal sector in Africa is arguably the most important, particularly in terms of job creation and supporting local livelihoods (Mbaye et al., 2020; Rogerson, 2018; Becker, 2004; Tichaawa, 2017; Brenton et al., 2014; van Eeden, 2011; Peberdy, 2007; Rogerson and Letsie, 2013; Benjamin and Mbaye, 2014). In their research on Francophone African countries, Mbaye et al. (2020) found that informal businesses comprised approximately $97 \%$ of private businesses. Moreso, de Haan (2020) posits that informal trading is the keystone sector for many African countries and consequently insists that further research into this 'grey economy' is necessary. This research acknowledges the potential for inclusive growth offered by the sector and responds to the calls of de Haan (2020) and others by focusing on the informal business tourism sector within Cameroon.

Rogerson (2014b) highlights that domestic business tourism is an extensive and undocumented economy, which often occurs in capital cities, or major business centres in Sub-Saharan African countries. In this study, it is argued that business tourism is one of the major forms of tourism in Cameroon, particularly in urban centres. In an earlier study which investigated the nature of business tourism in Cameroon, it was concluded that informal domestic business travellers constituted the dominant type of business tourists (Tichaawa, 2017). Accordingly, this study serves to broaden the scope of literature on this topic by exploring the nature and characteristics of informal domestic business tourism. In doing so, the study provides new theoretical insight into a relatively scarce area of tourism research. Furthermore, the present research strongly argues for the classification of informal traders as business travellers since it reflects the interactions amongst these individuals with sectors within tourism.

In order to contextualise the study within the business tourism discourse, the paper begins by unpacking the international literature on business tourism and underscores that the unique features within the developing context necessitate further research into this sector of tourism as it operates in the informal sector.

\footnotetext{
* Corresponding author
} 


\section{International literature on business tourism}

Marais et al. (2017) describe business tourism as the cross-section of industries, which involves the interactions between a myriad of stakeholders, including professionals, companies, policymakers, and professional event organisers, to meet the requirements and needs of business travellers. One of the earliest and most widely used definitions for business tourism was conceptualised by Davidson (1994:1), who affirmed that business tourism is one of the oldest forms of tourism, and is "concerned with people travelling for purposes which are related to their work". Accordingly, the concept of business tourism has been noted to apply to independent business trips and non-routine, group travel to attend meetings, conferences, exhibitions and incentive travel, commonly known as MICE tourism (Rogerson, 2015). The growing significance and expansion of business tourism, has been recognized as a direct consequence of globalisation and new organizational structures of production (Rogerson, 2015; Davidson, 2018; Marques and Pinho, 2021). Indeed, Marques and Pinho (2021) accrue globalisation as a natural promoter of business tourism owing to the fact that it led to the expansion of business opportunities worldwide, the creations of new forms of work, and leads the increasing need for industrial, commercial and knowledge expansion (Davidson, 2018; Rogerson, 2015). Indeed, it has been reported that business tourism is intertwined with the world's economy owing to the exchange of information, contacts and knowledge that occurs through business trips, MICE events and subsequent tourism activities (Rogerson, 2015; Spencer and Bavuma, 2018). Accordingly, some of the reasons for business travel have been related to training sessions, attending meetings, visiting clients, suppliers and sub-contractors, promoting products, and negotiating new business (Rogerson, 2015).

Business tourism has been identified as one of the key drivers of tourism growth worldwide (Alananzeh et al., 2019; Bueno et al., 2020; Mair and Jago, 2010; Rogerson, 2015). Business tourism scholarship often points to the use of business tourism as part of tourism-led urban regeneration and destination marketing strategies (Lau et al., 2005; Alananzeh et al., 2019; Buathong and Lai, 2017; Davidson, 2018). Indeed, many urban areas have invested in conference centres and business accommodations that are often needed for business travellers, and have established convention bureaus in becoming competitive business tourism destinations (Davidson, 1994; Buathong and Lai, 2017; Mair and Jago, 2010; Rogerson, 2015). The establishment of convention bureaus, which supports the competitive bidding for MICE events, stems from the acknowledgment of the socio-economic development impacts of business events, which has, in turn, created a competitive arena in which cities and countries attempt to capitalize on this tourism sector (Rogerson, 2015). Beyond attracting commercial and professional opportunities for the destination, the use of business tourism in urban development has been further accrued to the fact that business tourists are a highly lucrative market segment with some studies illustrating business tourists to have a higher spend than other types of tourists in the destination (Rogerson, 2014a; Marques and Pinho, 2021; Marais et al., 2017). Moreover, this sector of tourism has been described to have a highly controlled environmental impact, minimizes seasonality, and provide higher revenue for meetings venues and accommodations (Rogerson, 2015). Further, business tourism is identified to have a direct link to leisure tourism (Rogerson, 2015). In fact, business tourists are found to take part in some recreational and leisure activities during their stay at the destination (Rogerson, 2015). Kerr et al. (2012) concluded that MICE events, such as conferences and exhibitions, provide a unique opportunity to convert business tourists into return leisure tourists. The scholars explain that business tourists often 'test' the destination as potential holiday destinations while visiting for their MICE event, where such activity increases the destination awareness and reduces the risk of travelling by allowing the tourists to experience the destination first hand (Kerr et al., 2012).

The available writing on business tourism is overwhelmingly based on the 'Northern' conceptualization of business tourism, with the European Union, East Asia, North America, Australia and New Zealand being the contexts on which most scholarship is concentrated (Rogerson, 2014a). Commonly, researchers have investigated factors influencing the choice of destination for business events (see Haven-Tang et al., 2007; Byrne and Skinner, 2007; Dragićević et al., 2012; Marais et al., 2017; Alananzeh et al., 2019; Henderson, 2007), sustainability and development issues concerned with business tourism (Dwyer and Forsyth, 1997; Dwyer and Mistilis, 1999; Hoyer and Naess, 2001; Katsitadze and Natsvlishvili, 2017; Lau et al., 2005; Mair and Jago, 2010; Marques and Santos, 2017), and the use of business tourism as part of destination marketing for urban cities (Marques and Pinho, 2021; Cieslikowski, 2015). Predominantly, this literature on the northern or developed context focuses on the formal sector of business tourism - either domestic or international tourists travelling with the intent on attending MICE events (Rogerson, 2015). Incrementally, this focus is shifting to the developing context, with one major argument for this exploration stemming from the assertion that business tourism in the global south is not only a major segment of tourism in the region but that the sector takes on a different form and character as compared to its northern counterpart (Rogerson, 2014b).

\section{Business tourism in the developing context}

Generally, business tourism is approximated to constitute $25 \%$ of the international arrivals to Sub-Saharan Africa (World Bank, 2012; Christie et al., 2013). Citing the World Bank (2012) report, Rogerson (2014b) lists Cameroon, Burkina Faso, Niger, Nigeria, Guinea, Central African Republic, Democratic Republic of Congo, Malawi and Mozambique as having a substantial share of business tourism, accounting to close to $40 \%$ of the international tourism revenue. Indeed, for the tourism economy of many countries in the region, Rogerson (2014a; 2015) underscores that business tourism accounts for the leading edge. Despite the apparent significance of the sector, several scholars find the sector to be severely overlooked and undervalued (Rogerson, 2014a; Tichaawa, 2017; Coles and Mitchell, 2009; Marais et al., 2017). As such, these studies point to the importance of further examination of the sector in the region in order to understand the nature and character of the sector, and the subsequent impacts which would then inform policy that would enhance the contribution of business tourism to the national economies of these countries (Rogerson, 2014a; Tichaawa, 2017; Coles and Mitchell, 
2009). Coles and Mitchell (2009) further stress the significance of the sector, by highlighting the contrasting volumes of business tourists and leisure tourists' arrivals in the region, where the former is noted to consistently exceed the latter.

The undervalued nature of business tourism arises largely from the challenge in measuring the value of business tourism in these regions since many of these countries are labelled as 'emerging leisure destinations' thereby necessitating this sector of tourism (business tourism) to be viewed as a crucial component of international tourism (Rogerson, 2014a/b). Rogerson (2014a; 2014b) demonstrates that this imbalance results from a major portion of business tourism being unaccounted for in many countries in Sub-Saharan Africa. Indeed, in describing business tourism in Sub-Saharan Africa, several scholars indicate that the character of the sector in this region is in several ways contrasting relative to the developed context (Rogerson, 2014a; 2014b; 2015; Rogerson and Letsie, 2013; Timothy and Teye, 2005; Tichaawa, 2017; Brenton et al., 2014; Peberdy, 2007). Of particular significance is that business tourism in the developing context is dominated by the informal sector (Rogerson, 2014a; 2014b; 2015; Rogerson and Letsie, 2013; Timothy and Teye, 2005; Tichaawa, 2017; Brenton et al., 2014; Peberdy, 2007). Gladstone's (2005) earlier conceptualization of tourism in developing countries divides the industry into four categories across the lines of formal and informal sector tourism and international and domestic tourism, evident in Figure 1 below. Rogerson (2014a) affirms this categorization of tourism, and subsequently business tourism, in Sub-Saharan Africa as providing a departure point onto which the nature, impact and patterns of business tourism can be examined. Indeed, this structure indicates that business tourism in the region is not limited to MICE tourism and business meetings, as is the focus in the developed world, but rather spotlights a major activity in developing countries - the informal travelling for business purposes in the continent (Rogerson, 2014a). Accordingly, it is therefore imperative to examine both informal and formal business tourism to gain a holistic understanding of the sector.

Published research on business tourism in Sub-Saharan Africa approaches the phenomenon within the realms of the Northern concept (Rogerson, 2014b). Business tourism, as a component in cities' urban tourism strategies, has led to the growth of business hotels and conferencing facilities throughout the continent, with particular reference to major cities in the continent, being Johannesburg, Durban, Cape Town, Addis Ababa and Nairobi (Rogerson, 2014b). Indeed, much of the investment made in such facilities have been described as targeted towards the business tourism market (Rogerson, 2014a; Christie et al., 2013; Tichaawa, 2017). Some of this investment has been associated with quality accommodation standards, good transportation accessibility, the availability of recreational facilities and the general tourist attractiveness of the host destination (Sylla et al., 2015). As factors which tourists consider when selecting the business tourism destination, these features mirror those in the developed context (Dragićević et al., 2012; Marais et al., 2017; Alananzeh et al., 2019; Henderson, 2007). The following section details the existing literature on the informal sector of business tourism.

\begin{tabular}{cc|c|c|}
\multicolumn{1}{c}{} & \multicolumn{2}{c}{ Establishment } \\
\cline { 3 - 4 } Tourists & Foreign & $\begin{array}{c}\text { International formal } \\
\text { sector tourism }\end{array}$ & $\begin{array}{c}\text { International informal } \\
\text { sector tourism }\end{array}$ \\
\cline { 3 - 4 } & Domestic & $\begin{array}{c}\text { Domestic formal sector } \\
\text { tourism }\end{array}$ & $\begin{array}{c}\text { Domestic informal } \\
\text { sector tourism }\end{array}$ \\
\cline { 3 - 4 } & &
\end{tabular}

Figure 1. Formal and informal tourism (Source: Gladstone, 2005: 28)

\section{The informal economy and informal business tourism}

One distinguishing trait of developing countries, more especially in Sub-Saharan Africa is the informality of economic life (Rogerson, 2018; Benjamin and Mbaye, 2014). Becker (2004) explains that the sector had been 'discovered' in the early 1970s and, for a substantial period of time, to have been thought of as peripheral and marginal. During this period, it was widely assumed that low income and traditional economies could, with a combination of the right policies and resources, be transformed into the present-day dynamic and modern economies (Chen, 2012). It was incorrectly assumed that the surplus of unemployed individuals (taking part in microeconomic activities such as trading, food production and casual jobs) in these developing countries would be absorbed by the modern industrial sector once the economy of these countries developed further (Becker, 2004). This misconception within the developing context was termed the 'Lewis Turning Point' where wages were postulated to rise above subsistence level (Chen, 2012). Evidently, the sector had not been linked to the modern capitalist development, or formal economy, and therefore deemed to be a temporary phenomenon (Rogerson, 2018; Chen, 2012; Becker, 2004).

However, contrary to predictions, the informal economy did not disappear but rather grew to account for the major portion of the economy in developing countries (Chen, 2012; UNCTAD, 2019; Peberdy, 2007). As such, several scholars have strongly argued that the informal economy is a major force across the continent (Peberdy, 2000a; Rogerson, 2018; Becker, 2004; Tichaawa, 2017; Brenton et al., 2014; van Eeden, 2011; Peberdy, 2007; UNCTAD, 2019; Rogerson and Letsie, 2013; Benjamin and Mbaye, 2014). Indeed, the UNCTAD (2019) found the informal economy to be the main source of employment in the continent, employing $78.8 \%$ of people in Central Africa, $76.6 \%$ in Eastern Africa and $87 \%$ in Western Africa. Aside from the job generation potential inherent to the informal sector, it also serves as a significant contributor to poverty alleviation in these countries (Chen, 2012; van Eeden, 2011; Brenton et al., 2014; International Organisation for Migration [IOM], 2010). The growth of the informal economy is cited to be attributed to several factors including: the limited employment opportunities, barriers to the informal economy, weak institutions, the demand for low-cost goods and services, and uncommitted or unaware governments (Becker, 2004).

Firstly, the limited capacity of the formal economy, particularly within the prominent agricultural sector, to absorb the surplus labour, most notably young entrants, has increased the size of the informal economy where individuals have decided to carry out various informal activities to supplement their meagre household income (IOM, 2010; Becker, 2004; UNCTAD, 2019). Secondly, there are some barriers to entry into the formal economy, such as excessive costs and stringent, and often complex, government regulation which has influenced/'disincentivized people such that they remain 
in the informal economy (Becker, 2004; IOM, 2010). Thirdly, the limited capacity of formal institutions to provide incentives for structural reforms, such as providing training, education and infrastructure have all boosted the informal economy (Becker, 2004; IOM, 2010). Additionally, Becker (2004) argues that the demand for low-cost goods and services, from those employed in both the formal and informal economy has contributed to this growth.

Furthermore, studies have accrued economic hardships, poverty and the growing number of women entering the labour markets as other reasons for the growth of this informal sector (Becker, 2004; UNCTAD, 2019; Rogerson, 2014b; van Eeden, 2011; IOM, 2010; Brenton et al., 2014). Moreover, van Eeden (2011) is of the view that the informal economy primarily comprises survivalist entrepreneurs who seek to capitalize on lucrative business opportunities. Such views echo the position of Peberdy (2000a) who found that some of those involved in the informal economy were purely entrepreneurial individuals with no interest in joining the formal economy and that these individuals enjoyed autonomy in their business activity (Peberdy, 2000a). Finally, the belief that the informal economy will soon die out has resulted in minimal government intervention (Becker, 2004). In concurrence with this view, the UNCTAD report found that location and level of education are key determining factors in whether individuals are employed in the formal or informal sectors (UNCTAD, 2019). Upon further analysis, it was concluded that individuals most likely to be employed in the formal sector are those with secondary and tertiary school education and those residing in urban areas (UNCTAD, 2019; Afrika and Ajumbo, 2012). Conversely, individuals found within the rural regions of the continent without formal education are most likely to be employed in the informal economy (UNCTAD, 2019).

Becker (2004) argues against confining the concept of informality to a specific sector of economic activity since it crosses over to many sectors, one of which is tourism. Rogerson (2018) asserts that further investigation in the informality of tourism is needed as it is arguably a fundamental structural feature in the industry across the developing world. The subordinate nature of informal tourism, and consequently business tourism, has been confirmed by several studies (Rogerson, 2014a, 2014b, 2015, 2018; Rogerson and Letsie, 2013; Tichaawa, 2017). Drawing reference to Figure 1 above, informal sector business tourism similarly is both an international and domestic phenomenon (Gladstone, 2005). The UNCTAD (2019) considers informal business tourism activities as conducted by small, vulnerable and unregistered traders who travel between countries and/or within regions of the country.

This trade comprises the movement of goods between cities, or cities and rural areas (UNCTAD, 2019; van Eeden, 2011). The existing literature on informal business tourism prominently focuses on the business activities of shoppers and traders crossing international borders (Rogerson, 2018; Timothy and Teye, 2005; Rogerson and Letsie, 2013; Brenton et al., 2014; van Eeden, 2011; Peberdy, 2007). These individuals, often referred to as informal cross border traders, constitute a significant portion of inter-regional travel in Sub-Saharan Africa (Rogerson, 2013; UNCTAD, 2019; Benjamin and Mbaye, 2014; Chen, 2012). Much of the available literature has focused on Southern Africa (see Ezeuduji, 2013; Peberdy, 2000a, 2000b, 2007; Rogerson, 2014a, 2014b, 2018, Rogerson and Lestie, 2013), illustrating the uneven expansion of regional tourism across Sub-Saharan Africa. These studies have revealed informal international business tourism, (now referred to as informal cross border trading) to be between the communities of informal traders in neighbouring Southern African countries and South Africa (Ezeuduji, 2013).

More specifically, this regional travel is between South Africa and Lesotho, Swaziland, Malawi, Mozambique and Zimbabwe (Rogerson, 2014b; Rogerson and Letsie, 2013; Peberdy, 2000a). Since its transition to democracy and the subsequent deregulation of the informal economy, South Africa has become a major magnet for regional tourists and traders (Rogerson, 2014a; Peberdy, 2000a). In one of the earliest studies on informal cross border trading in Southern Africa, Peberdy (2000a) explains that informal cross border trade comprises of micro to medium scale enterprises. Typically, research has found these informal cross border traders to be young male entrepreneurs in most regions of Sub-Saharan Africa however in Southern Africa, these entrepreneurs are noted to be mostly women (UNCTAD, 2019; Rogerson, 2014b; Chen, 2012; Peberdy, 2000a, 2000b; Afrika and Ajumbo, 2012). These women adopt cross border trading as a means to support their families, more especially their children through schooling (Rogerson, 2014b; Benjamin and Mbaye, 2014). Often, these informal cross border traders source various goods from urban centres like Johannesburg, such as clothing, groceries, fresh fruits, craft goods and other items (Rogerson, 2014b; Brenton et al., 2014; van Eeden, 2011; Peberdy, 2007). Other items common in this informal cross border trade relates to manufacturing goods, re-exports (such as tobacco, electronic appliances tools and simple machines) and sub-standard goods (such as fuel and precious metals) (Afrika and Ajumbo, 2012). In her study, van Eeden (2011), highlights the role played by migrants in this informal activity by drawing reference to the foreign entrepreneurs, located near popular tourist destinations in South Africa, who source their goods (often traditional crafts and art) from their home country.

Additionally, Peberdy (2000a) found that many of the cross border traders had been travelling to the urban areas to obtain stock, where orders were taken from formal businesses in their home country, or family and friends. Major cities, such as Johannesburg, attract many informal cross border traders (and even domestic informal traders) owing to the variety of goods found in the city as well as the price competitiveness on which traders can capitalize (Rogerson, 2018; van Eeden, 2011; Boonchai and Freathy, 2018; Peberdy, 2000b). Peberdy (2007) found that some informal cross border traders had been travelling frequently, carrying low value goods, as opposed to travelling infrequently with high-value loads. Their travel behavior is further noted to be quite different from their counterparts (international business tourists), in that these traders often do not stay at formal accommodation establishments, rather they stay with family and friends, or inside their vehicles, often buses and vans (Rogerson, 2018; Peberdy, 2000b; Afrika and Ajumbo, 2012).

While the informal cross border trader industry is largely undocumented, this sector of business tourism has been acknowledged to have a significant socio-economic contribution to the regions in which they operate (IOM, 2010; Peberdy, 
2007; Brenton et al., 2014; van Eeden, 2011; UNCTAD, 2019). Informal cross border trade has been recognized to have a complex, but somewhat positive relationship with the formal sector (Peberdy, 2000a; Rogerson, 2018). Further, this type of business tourism has been linked to local economic development, in which Rogerson (2018) found that this activity results in lower economic leakages and which subsequently has a higher multiplier effect. For instance, in Johannesburg, Peberdy (2000a) found that the profits generated by these informal cross border traders by formal business establishments had been invested back into the retail and manufacturing sectors. However, it is important to also note the adverse nature of this economy as it presents some risks and vulnerability of those involved owing to the lack of regulations and government intervention (Organisation for Economic Co-operation and Development [OECD], 2019). These include the sexual exploitation of women, corruption at the national borders, and other illegal activities that should further be considered when examining the potential of informal cross border tourism for socio-economic development (OECD, 2019, Tichaawa, 2017).

The above discussion augments the numerous studies that have concluded the importance of including informal cross border tourists into the policy framework of the region on the basis that this would translate to future growth (Brenton et al., 2014; Chen, 2012; Rogerson, 2014a; 2014b; Afrika and Ajumbo, 2012; van Eeden, 2011). Such literature has highlighted the potential for this economic activity to support the ongoing efforts of many countries in Sub-Saharan Africa towards poverty alleviation and regional development (Brenton et al., 2014; Chen, 2012; Rogerson, 2014a; 2014b; Afrika and Ajumbo, 2012; van Eeden, 2011; Peberdy, 2000b). Further, Afrika and Ajumbo (2012) underscore the importance of shifting away from viewing informal trade as a criminal activity, but rather recognizing and harnessing the economic potential in this sector. In addition to creating a favourable policy environment for informal cross border traders, Afrika and Ajumbo (2012) suggest that such considerations should further apply to the business and institutional environment. This has been translated to improving border infrastructure, mainstreaming informal cross border trade in the national governing policies, establish linkages between traders and businesses in the formal economy, provide financial and technical support to assist traders, and improving border security to curb corruption and wrongful behavior (Afrika and Ajumbo, 2012; OECD, 2019; Peberdy, 2000b).

The last category is the informal sector business tourism. Scheyvens (2007) coins domestic tourism as the 'poor cousin' of the international tourism market (Rogerson and Lestie, 2013). Within the business tourism typology presented by Gladstone (2005), informal domestic tourism has received the least attention in business and tourism scholarship. Only a few investigations exist on this type of business tourism (Rogerson and Lestie, 2013; van Eeden, 2011). Of interest is the assertion by numerous studies that informal traders comprise the majority of the domestic business tourism market in Sub-Saharan Africa (Gladstone, 2005; Rogerson and Lestie, 2013; Rogerson, 2015; Tichaawa, 2017). Indeed, Tichaawa (2017) concluded domestic business tourism in Cameroon to have been dominated by informal traders. The existing literature on informal domestic business tourism shows similar attributes to informal international business tourism, particularly in terms of motivation and travel behaviours. Like informal cross border traders, the informal domestic business travellers frequent urban centres due to the availability and varieties of products typically not found in their home environments (Rogerson, 2018; Rogerson and Lestie, 2013; van Eeden, 2011). Additionally, these are amongst one of the self-sufficient travellers, bringing their groceries to prepare their meals wherever they rest (Rogerson and Lestie, 2013). Rogerson and Lestie (2013) further describe these informal sector domestic business tourists as entrepreneurs whose activities link urban cities to rural areas and small cities in the country. The scholars further argue the significance of these types of travellers, citing the inherent pro-poor nature of this economic activity.

\section{The case of Cameroon}

The setting for this present study is Cameroon - an emerging destination in Central Africa. Cameroon is often referred to as Africa in miniature, or Africa in one country, as the geographical and ecological features, coupled with the local people and their culture, enables tourists to experience the vibrant social tapestry of Africa (Tichaawa, 2017; Tichaawa and Kimbu, 2019; Harilal et al., 2019; Kimbu and Ngoasong, 2013). The country is rich in natural and cultural attractions, providing the country with immense tourism potential (Tichaawa, 2017; Kimbu, 2011, 2012; Harilal et al., 2019). Indeed, the country began developing its tourism industry more than forty years ago when it established the General Delegation of Tourism in 1981, which later was enlarged to become the fully-fledged Ministry of Tourism and Leisure (MINTOUR) in 1989, responsible for tourism development and environment protection and management (Kimbu and Ngoasong, 2013).

Similar to many countries in the region, Cameroon has positioned tourism as a sector to aid in the socio-economic development of the country (Tichaawa, 2017). Subsequently, the sector has been geared towards improving the livelihoods of the population, providing employment and entrepreneurial opportunities, and alleviating poverty (Kimbu and Ngoasong, 2013, 2016; Harilal et al., 2019). However, tourism development in the country is hampered by poor policy development and coordination, poor quality of accommodation, lack of human and financial capital, bad image and corruption (Kimbu, 2012; Harilal et al., 2019; Tichaawa, 2017). While the tourism sector of the country is primarily driven by the leisure market and directed to ecotourism experiences, other emerging forms of tourism prevalent in Cameroon include cultural tourism and business tourism, with the present study focusing on the latter. Kimbu (2012) reported a large share (40\%) of international arrivals to Cameroon to be related to business travel purposes. Business tourism in Cameroon is an underresearched focus, particularly when taking cognizance of the wide-scale impact of the sector (both within its formal and informal nature). The foundation of the present study was provided by an earlier study which concluded that business tourism in Cameroon is largely dominated by domestic informal traders (Tichaawa, 2017). From this basis, this study further examines the nature and characteristics of this unknown, and important segment of tourism, as previously argued, by using Douala as a case study site and through specifically focusing on domestic informal traders. 
The selection of Douala stems from the fact that this major gateway city is the economic capital of Cameroon and is the most populated city with a recorded 3 million inhabitants in 2016 (Kimbu and Ngoasong, 2016). Indeed, Douala is known for a wide range of local and commercial markets which are popular for the selling and purchasing of goods from other geographic areas in the country. The study adopts a mixed-method research design. The limited tourism (specifically informal business tourism) research in Cameroon necessitates the utilisation of mixed-method to enable the collection of the required data. By way of a purposive sampling approach, the research compiled the views and opinions of 377 informal traders in the city of Douala. The research instrument used was semi-structured questionnaire surveys which intended to profile the respondents, with the focus on their travel characteristics and their spending patterns. Further, the instrument sought to categorize the groups of informal business traders. These traders were purposively identified with the assistance of trained fieldworkers placed at various intercity bus stations and local markets.

\section{RESULTS}

The study sought to examine the geographical origins of the informal business traders visiting Douala. These traders mainly originated from five regions. As shown in Table 1, the majority share of the traders came from the West Region (34.1\%), followed by the South West $(28.9 \%)$ and North West (23\%). Interestingly, the city received substantially fewer individuals from the Center Region (7.2\%) and South Region (5.3). The remaining share of the respondents were found to have originated from other regions of the country $(1.5 \%)$. The findings may illustrate the influence of the city to the neighbouring regions, as the regions prevalent in the study sample are the immediate neighbours of Douala. Similarly, it can be postulated that the informal traders in the further regions may prefer to travel to Yaounde for informal trading rather than Douala. To understand the nature and characteristics of informal business traders, it is imperative to profile these groups. Table 2 below provides a profile of the informal business travellers in Douala.

As illustrated in the table, there was an almost equal proportion of female $(52.3 \%)$ and male $(47.7 \%)$ traders. The findings confirm those of previous studies, in that women, comprise the dominant informal traders (see UNCTAD, 2019; Peberdy, 2000a, 2000b; Afrika and Ajumbo, 2012; Becker, 2004; Benjamin and Mbaye, 2014; Rogerson, 2014b). The average age of the traders was calculated at 28 years old and they all had attained their secondary school qualification, with $32.8 \%$ of the respondents having attained higher education qualifications. In terms of their travel behaviours, the findings show that most of the respondents had travelled by bus (79.6\%), in which they make frequent trips to Douala to source and sell their product. Indeed, the survey shows that these traders had travelled to the city between 9 and 15 times in a year (97\%), and had short stays that lasted between 3 and 4 days (80\%), in which the majority $(66 \%)$ had stayed with either friends or relatives and the others in low budget hotels. Further, most of the respondents had indicated that they made their payments in cash $(82 \%)$ - a common feature found in many informal business travellers in Sub-Saharan Africa (see Peberdy, 2000a, 2000b; Rogerson, 2014b).

Table 1. Origin of Informal Domestic Business Travellers

Table 2. Profile of Informal Domestic Business Travellers

\begin{tabular}{|l|l|}
\hline Origin & \% \\
\hline West & 34.1 \\
\hline South West & 28.9 \\
\hline North West & 23 \\
\hline Center & 7.2 \\
\hline South & 5.3 \\
\hline Other & 1.5 \\
\hline
\end{tabular}

Table 3. Spending of Informal Domestic Business Travellers

\begin{tabular}{|l|l|}
\hline Besides business, how money was spent & In \% \\
\hline Shopping & 97 \\
\hline Food and beverage & 89 \\
\hline Transport (within the city) & 86 \\
\hline Gift/ souvenirs for family & 90 \\
\hline Entertainment and nightlife & 14 \\
\hline Visiting attractions (sightseeing) & 9 \\
\hline
\end{tabular}

\begin{tabular}{|l|l|}
\hline \multicolumn{1}{|c|}{ Characteristics } & \multicolumn{1}{c|}{ Key findings (in \%) } \\
\hline Gender & Female (52.3); Male (47.7.) \\
\hline Age & $\begin{array}{l}\text { Ranged between 19 - 57 years. Average age } \\
\text { was 28 years }\end{array}$ \\
\hline $\begin{array}{l}\text { Highest level of education } \\
\text { attained }\end{array}$ & $\begin{array}{l}\text { High school (39.4); Diploma/degree (32.8); } \\
\text { secondary school (15.5) and; primary school (12.3) }\end{array}$ \\
\hline Mode of transportation & $\begin{array}{l}\text { Bus (79.6); Own transport (11.9); By other } \\
\text { means including motorbikes (9.5) }\end{array}$ \\
\hline Frequency of visits & $\begin{array}{l}\text { 97.9 are regular visitor who +make between 8 } \\
\text { and 15 trips in a year }\end{array}$ \\
\hline Payments & $\begin{array}{l}\text { Trade in cash (82); Accept mobile money } \\
\text { (ewallet) (18) }\end{array}$ \\
\hline Length of stay (in days) & Short stays between 3 and 4 days (80) \\
\hline Type of accommodation & $\begin{array}{l}\text { Stay with friends or relatives (66); Low budget } \\
\text { hotels (34) }\end{array}$ \\
\hline
\end{tabular}

\section{Nature of informal business tourists}

Understanding the nature of informal business tourism in Cameroon necessitates further examination of these types of tourists. The current study found that these individuals lacked awareness of the sector. Informal domestic traders are not aware of the domestic travel sector, or that they are active participants in this local economy. These individuals consider themselves to be business people - trading from one area to the other. Their focus therefore is on the activity itself, and not necessarily of the travel component involved in this activity. Subsequently, these tourists do not see themselves as being travellers, or being involved in the tourism industry. Contrary to their views, evidence suggests that they are travellers, they use transportation from one city to the next city, or one rural area to an urban area. These travellers spend money on accommodation and food, and in some cases, there is a strong visiting friends and relatives (VFR) link to informal business travel. Despite this, informal business travelers are not aware that they are making a meaningful contribution to the overall tourism receipts of Cameroon.

Moreover, there is a significant lack of awareness of regulations. Inasmuch as there are policies that exist, from a national to a local level, to regulate businesses, these informal domestic traders have the ability to identify gaps (or loopholes) so as to not comply with certain issues, of which tax is the most prominent. An example of this, would be the nomadic nature of some 
of these informal businesses, moving away from one place to the other. Finally, amongst the informal business travelers are those that try to reduce travel costs as much as possible. They make use of various ways to minimize their budgets, including VFR. This is a major, and overlooked, aspect of informal business travel. Owing to the frequency of their travels, these traders create friendships in their sourcing or selling destinations where they can spend their overnight stay. Further, some also form friendships with their business partners. This was found to be very prominent amongst those travelling from rural to urban areas to source goods as they would spend the night with those they had sourced goods from.

\section{Categories}

From the survey, 5 distinct categories of informal business travellers were identified. The first of these categories included informal salespeople - known locally as 'Buyam-Sellam'. This category of informal trader had also been noted in a previous study on the research area in Cameroon (Tichaawa, 2017). The informal salespeople own stalls in Douala and trade in a range of goods in the city. The second category of informal traders comprises of the shop owners. This category of informal traders are those who can be tracked as they either own shops or stalls. The shop owners include craftsman and women, selling their original (or purchased) crafts and arts. Interestingly, the findings show that this group of traders travel to purchase items in order to resell in their shops.

The study found that their visits are characterized by shorter stays of about 3 days. The herdsmen, who trade in cattle and livestock were the third category of informal traders identified. Herdsmen are nomadic men; they travel for months at a time with their livestock to various areas to trade in cattle (buying and selling). They are characterised by their longer stays, usually staying in cities such as Douala for 3 months. The fourth category was the local farmers, who sell farm produce (i.e. cash crops such as vegetables, bananas, tubers and cocoa) at various local markets in the city. The fifth, and final, category of informal traders identified were wholesalers. Wholesalers act as intermediaries between the suppliers (farmers) and the sellers (i.e. salespeople and shop owners). This group of informal traders buy farm produce from rural areas and transport them to urban areas, such as Douala. Besides individual purchasing, they form informal cooperatives and buy at wholesale to reduce travel logistical costs. Moreover, it is important to note that the above categories of informal business travelers had utilized a few payment methods. To a large extent, cash was the most frequently utilized method of trading. Other cash payment methods had included mobile money transfers and post payment of goods. Such findings confirm the informality of these activities.

\section{The attraction to trade in the informal sector}

The research uncovered five main reasons for the engagement in the informal sector. The most commonly stated reason for the involvement in the informal sector related to the lack of, and inability to find, formal employment. The respondents explained that there were not many available work opportunities from both the private sector and the government. As such, the informal entrepreneurs were left with the option of striking out on their own through informal trading. Further, considering a larger share of the respondents were female, the motivation to enter into the informal trading sector could be linked to the need to provide some financial assistance to their familities.

Following, some of the respondents indicated that their participation in informal trading served to supplement their formal income. This could be attributed to the developing nature of the country, which could reflect in the low pay received. Therefore, the findings may suggests that those who have managed to find some informal employment in the formal sector still experience the risk of low income. Further, the respondents mentioned that they found the informal business trading sector a lucractive one. This could be related to the comparative financial differences between the informal and formal sectors, primarily the substantially less (and someone non-existance) tax fees, which subsequently makes their income undocumented. Moreover, as presented in the above results, these informal entrepreneurs primarily deal with cash transactions, thereby limiting the bank charges for their trade dealings.

Another frequently mentioned reason for the involvement in the informal sector was found to be the lack of trust in government and corruption. Indeed, these informal entrepreneurs affirmed their preference to be independent rather than to rely on their national government. Corruption remains a powerful inhibitor to the further development of many countries in Sub-Saharan Africa, and the respondents affirm this act to have limited to the opportunities for growth in the country, thus their predominance in the informal sector. Furthermore, the desire to run a big business in the future constituted as one of the common reasons offered by the study respondents. The informal sector is arguably the largest economic activity in Cameroon, and in the rest of the Sub-Saharan African countries. The poor conditions, service delivery and development had created a market for these entrepreneurs to provide goods that are not readily available. Accordingly, there is and will continue to be demand for informal traders, particularly considering their relatively more affordable prices as compared to formal institutions. Further, these entrepreneurial aspirations may be considered in relation to the above discussion, where the lack of formal employment opportunities had led to alternative livelihood means.

\section{Spending}

Finally, the study found it important to understand the spending patterns of the informal domestic business travellers. This section of the questionnare was asked in order to explore the economic spending at the city of Douala linked to these informal business tourists and it allowed for multiple responses to be offered. The findings in Table 3 below illustrates that majority of the respondents had spent money on shopping (97\%), gifts and souvenirs (90\%), food and beverage (89\%) and transport within the city $(86 \%)$. Accordingly, the findings illustrate the economic potential of these types of travellers and the need to consider them within tourism planning and development. Similarly, while the majority 
had indicated that they stay with friends or relatives during their time in Douala, their spending in the city could enhance local economic development. Interestingly, the activities that directly relate to social and tourism activities, being entertainment and nightlife and visiting attractions, received low spending - 14\% and 9\% respectively. This may suggest the difference between informal and formal business travellers, where the latter may suppliment their trip with additional leisure activities whereas the former is more deliberate in how they spend money during their trip

\section{DISCUSSION}

Informal business tourists are arguably an undervalued segment of business tourism (Rogerson, 2014b; UNCTAD, 2019). In unpacking the nature and charactertics of this form of business travel, the study confirms and builds upon previous studies' findings, particularly regarding the profile of these individuals (UNCTAD, 2019; Peberdy, 2000a; Rogerson, 2014a, 2014b, 2015, 2018; Rogerson and Letsie, 2013; UNCTAD, 2019). Indeed, women make up a large portion of these travellers, in which the UNCTAD (2019) attest their motivation to stem from the need to provide support to their familities. Further, the findings illustrate that while there is a wide age range of those involved in informal trade, the dominant share are those in the youth category. These two demographic profiles strongly relate to the major desire to empower youth and women in the Sub-Saharan African context. This is largely due to the lack of availability of jobs in the formal sector, as well as the lack of access to entrepreneurial opportunities due to the low levels of education and access to finance. The high unemployment and poverty levels prevalent in many Sub-Saharan African countries have also led to the growth of the informal business sector. Indeed, amongst the most common reasons provided for entrering into the informal sector was the limited employment opportunities available, which was further supported in that education profiles of the individuals surveyed were relatively good, where many had attained their secondary school qualification, and approximately a third of them had either a diploma or degree. As such, the study finds the motivations to travel are comparatively different from formal domestic and international business tourists. Further, related to their demographic profiles, the study shows this segment to be from surrounding regions which could be attributed to two factors, the first being the informal trade opportunities offered in Douala and the second being that most of the respondents are from Anglophone regions. Under the political divide in the country, at the time of the study, it can be assumed that those residing in Anglophone parts may find it easier to travel within these regions.

The study illustrates the strong need for further understanding of informal domestic business travellers, as they exhibit some very different characteristics from their formal counterparts. Rogerson (2014b) finds the exclusion of informal business domestic traders within the business tourism discourse to be owed to the fact that these individuals are often not perceived, or seen to qualify, as tourists. The present study findings contests this perception, or definition of, business tourism to not fit the reality of the developing context. In fact, when considering the categorization of informal traders identified in the findings, there is a clear and major travel component involved in their business. The poor access to public goods necessitated many of these entrepreneurs to travel to the economic hub, being Douala, to stock up on the required (and lacking) goods in order to sell them in their own communities. These individuals utilize various sectors of the tourism industry, such as transportation, food and beverage and for the minority, accommodation. Therefore, the present study concurs with the assertion by Kimbu and Ngoasong (2016), in that the informality of these activities means that the socio-economic impact of these travellers is undocumented. In fact, the findings illustrate that these traders have a significant contribution to local economic development. Inasmuch as they may save money on accommodation, the informal domestic business travellers spend money in other sectors in the local economy. Further, considering that they often stay for 3 or 4 days, taking these trips to the city quite frequently throughout the year, it constitutes an economic force necessitating further consideration and inclusion in tourism planning. Specifically, Rogerson and Letsie (2013) further position these informal business travellers as pro-poor owing to their spending (i.e. local impacts) and themselves as entrepreneurs. Moreover, similar to the formal business tourism sector, the focus is on the urban region, where these entrepreneurs are drawn to major economic cities to conduct their business. Indeed, in an earlier study, it was found that a significant portion of the visitors in hotels in Douala and Yaounde were domestic informal business tourists (Tichaawa, 2017). Thus, the further growth and development of urban destinations in Cameroon should consider the contribution that this market segment could have, if strategically accounted for.

Similarly, these informal business traders are defined as domestic informal business tourists, engaged in several economic activities, which link capitals and rural (and small) areas (Rogerson, 2018; UNCTAD, 2019). Indeed, the findings reveal that these travellers use Douala to purchase goods which are not easily available through the local markets. As such, informal business travel forms a very important element in the local development in rural communities in Cameroon. Beyond the tourism benefits, these individuals provide an important social role in communities, by providing necessary products that are not easily obtained in the less developed (and rural) areas. As such, informal business tourism can contribute toward inclusive growth and development in Sub-Saharan Africa (Mbaye et al., 2020).

\section{CONCLUSION}

The provided analysis of the nature of business tourism in Cameroon reveals its character and dynamics to exhibit parallels with other studies conducted in urban Sub-Saharan Africa. The importance of these different forms of informal business travels in urban Cameroon confirms the significance of this category of business tourists (Rogerson, 2014a, 2014b, 2015, 2018; Rogerson and Letsie, 2013; UNCTAD, 2019). Amongst the few of its kind, the present study draws attention to an important sector of business tourism which is able to, if properly developed, contribute towards local economic development. Along with the work of Rogerson (2014b), the current study affirms informal domestic traders 
to be tourists, owing to their interaction with several travel sectors, and therefore argues that they should be considered within tourism policy development and planning, particularly in the context of domestic tourism in urban destinations.

Similarly, Kimbu and Tichaawa (2018) found Cameroon to be a destination with strong tourism potential, but which struggles to be competitive in terms of attracting international tourists (and pre-COVID-19 data shows figures of just over 1 million). Thus, the focus on the development of domestic tourism should be a key priority for government, given the emerging evidence of its significance, through the informal domestic tourism sector.

Moreover, according to WTTC figures, domestic travel spending alone in Cameroon generated $71.2 \%$ of tourism and travel share in GDP in 2017. Informal domestic business tourism in Cameroon is not a hidden economy, rather it is a visible one that drives entrepreneurship for youth and women. The informal domestic business tourism also drives the local economy and its multiplier effect is widespread amongst the different economic sectors of Cameroon. Finally, the current study found VFR to support informal domestic business travel, and it argues for further research into this field, particularly in investigating the relationship between VFR travel and informal business. This could contribute towards capturing the aforementioned benefits of informal domestic business travel.

\section{REFERENCES}

Afrika, J.K., \& Ajumbo, G. (2012). Informal Cross Border Trade in Africa: Implications and Policy Recommendations, African Development Bank Economic Brief, Tunis.

Alananzeh, O., Al-Badarneh, M., Al-Mkhadmeh, A., \& Jawabreh, O. (2019). Factors influencing MICE tourism stakeholders' decision making: The case of Aqaba in Jordan. Journal of Convention \& Event Tourism, 20(1), 24-43. https://doi.org/10.1080/15470148.2018.1526152

Becker, K.F. (2004). The informal economy, SIDA, Stockholm.

Benjamin, N., \& Mbaye, A.A. (2014). Informality, growth and development in Africa. World Institute for Development Economics Research (WIDER) Working Paper 2014/052. UNU-WIDER, Helsinki.

Boonchai, P., \& Freathy, P. (2020). Cross-border tourism and the regional economy: A typology of the ignored shopper. Current Issues in Tourism, 23(5), 626-640. https://doi.org/10.1080/13683500.2018.1548579

Brenton, P., Dihel, N., Hoppe, M., \& Soprano, C. (2014). Improving behaviour at borders to promote trade and formalisation: The charter for cross border traders. Policy Note No. 41, The World Bank, Washington DC.

Bueno, A.R., Urbistondo, P.A., \& Martínez, B.A. (2020). The MICE tourism value chain: Proposal of a conceptual framework and analysis of disintermediation. Journal of Convention \& Event Tourism, 21(3), 177-200. https://doi.org/10.1080/15470148.2020.1740851

Byrne, P., \& Skinner, H. (2007). International Business Tourism: Destination Dublin or Destination Ireland? Journal of Travel \& Tourism Marketing, 22(3-4), 55-65. https://doi.org/10.1300/J073v22n03_05

Buathong, K., \& Lai, P. (2017). Perceived attributes of event sustainability in the MICE industry in Thailand: A viewpoint from governmental, academic, venue and practitioner. Sustainability, 9(7), 1151. https://doi.org/10.3390/su9071151

Chen, M.A. (2012). The informal economy: Definitions, theories and policies. WIEGO Working Paper No. 1. WIEGO, Manchester.

Cieslikowski, K. (2015). Business Tourism as Innovative Product for Destinations. Innovative (Eco-) Technology, Entrepreneurship and Regional Development. Conference proceedings.

Christie, I., Fernandes, E., Messerli, H., \& Twining-ward, L. (2013). Tourism in Africa: Harnessing Tourism for Growth and Improved Livelihoods, The World Bank, Washington, DC.

Coles, C., \& Mitchell, J. (2009). Pro Poor Analysis of the Business and Conference Value Chain in Accra: Final Report, Overseas Development Institute, London.

Davidson, R. (1994). Business Travel, Pitman, London.

Davidson, R. (2018). Business Events, Routledge, London.

De Haan, A. (2020). Foreword. In Formal and informal enterprises in Francophone Africa: Moving towards a private sector (pp. xixxxi). International Development Research Centre, Ottawa, Canada.

Dragićević, V., Jovičlć, D., Blešlć, I., Stankov, U., \& BošKović, D. (2012). Business Tourism Destination Competitiveness: A Case of Vojvodina Province (Serbia). Economic Research-Ekonomska Istraživanja, 25(2), 311-331. https://doi.org/10.1080/1331677X.2012.11517510

Dwyer, L., \& Forsyth, P. (1997). Impacts and benefits of MICE tourism: A framework for analysis. Tourism Economics, 3(1), 21-38. https://doi.org/10.1177/135481669700300102

Dwyer, L., \& Mistilis, N. (1999). Development of MICE Tourism in Australia. Journal of Convention \& Exhibition Management, 1(4), 85-100. https://doi.org/10.1300/J143v01n04_07

Ezeuduji, I.O. (2013). Nigerian tourists to South Africa: Challenges, expectations and demands. Acta Commecii, 13(1), 170-179. http://dx.doi.org/10.4102/ac.v13i1.170

Gladstone, D. (2005). From pilgrimage to package tour: Travel and tourism in the Third World, Taylor and Francis, Abingdon.

Harilal, V., Tichaawa, T.M., \& Saarinen, J. (2019). Development without policy: Tourism Planning and Research Needs in Cameroon, Central Africa. Tourism Planning \& Development 16(6), 696- 705. https://doi.org/10.1080/21568316.2018.1501732

Haven-Tang, C., Jones, E., \& Webb, C. (2007). Critical Success Factors for Business Tourism Destinations. Journal of Travel \& Tourism Marketing, 22(3-4), 109-120. http://dx.doi.org/10.4102/ac.v17i1.423

Henderson, J.C. (2007). Hosting Major Meetings and Accompanying Protestors: Singapore 2006. Current Issues in Tourism, 10(6), 543557. https://doi.org/10.2167/cit322.0

Hoyer, K.G., \& Naess, P. (2001). Conference Tourism: A Problem for the Environment, as well as for Research? Journal of Sustainable Tourism, 9(6), 451-470. https://doi.org/10.1080/09669580108667414

Katsitadze, N., \& Natsvlishvili, I. (2017). Development Opportunities of Mice Tourism in Developing Countries: Case of Georgia. The Role of State Regulation and Policy in Tourism Development (Case. of Georgia). 23rd EBES Conference-Madrid Procedongs, September 27-29.

Kerr, G., Cliff, K., \& Dolnicar, S. (2012). Harvesting the "Business Test Trip": Converting Business Travelers to Holidaymakers. Journal of Travel \& Tourism Marketing, 29(5), 405-415. https://doi.org/10.1080/10548408.2012.691390

Lau, C.K.H., Milne, S., \& Johnston, C.S. (2005). MICE, ICT and Local Economic Development. Journal of Convention \& Event Tourism, 7(1), 61-75. https://doi.org/10.1300/J452v07n01_05 
Kimbu, A.N. (2011). The challenges of marketing tourism destination in Central African Subregion: The Cameroon example. International Journal of Tourism Research, 13, 324-336. https://doi.org/10.1002/jtr.853

Kimbu, A.N. (2012). Attainment of MDGs through tourism in Central African sub-region: Implications for local economic development in Cameroon. Revista de Turismo y Patrimonio Cultural, 10(2), 3-16. http://dx.doi.org/10.25145/j.pasos.2012.10.022

Kimbu, A.N., \& Ngoasong, M.Z. (2013). Centralised Decentralisation of Tourism Development: A network perspective. Annals of Tourism Research, 40, 235-259. https://doi.org/10.1016/j.annals.2012.09.005

Kimbu, A.N., \& Ngoasong, M.Z. (2016). Women as vectors of social entrepreneurship. Annals of Tourism Research, 60, 63-73. https://doi.org/10.1016/j.annals.2016.06.002

Kimbu, A.N., \& Tichaawa, T.M. (2018). Sustainable development goals and socio-economic development through tourism. GeoJournal of Tourism and Geosites, 23(3), 780-796. https://doi.org/10.30892/gtg.23314-328

Mair, J., \& Jago, L. (2010). The development of a conceptual model of greening in the business events tourism sector. Journal of Sustainable Tourism, 18(1), 77-94. https://doi.org/10.1080/09669580903291007

Makoni, L., \& Tichaawa, T.M. (2021). Impact analysis of the COVID-19 pandemic on the informal sector business tourism economy in Zimbabwe. African Journal of Hospitality, Tourism and Leisure, 10(1), 165-178. https://doi.org/10.46222/ajhtl.19770720-93

Marais, M., du Plessis, E., \& Saayman, M. (2017). Critical success factors of a business tourism destination: Supply side analysis. Acta Commercii - Independent Research Journal in the Management Sciences, 17(1), 1-12. https://doi.org/10.4102/ac.v17i1.423

Marques, J., \& Pinho, M. (2021). Collaborative research to enhance a business tourism destination: A case study from Porto. Journal of Policy Research in Tourism, Leisure and Events, 13(2), 172-187. https://doi.org/10.1080/19407963.2020.1756307

Mbaye, A.A., Golub, S., \& Gueye, F. (2020). Formal and informal enterprises in Francophone Africa: Moving towards a private sector, International Development Research Centre: Ottawa, Canada.

Peberdy, S. (2000a). Border crossings: Small entrepreneurs and informal sector cross-border trade between South Africa and Mozambique. Tijdschrift voor Economische en Sociale Geografie, 91, 361-378. https://doi.org/10.1111/1467-9663.00124

Peberdy, S. (2000b). Mobile entrepreneurship: informal cross-border trade and street trade in South Africa. Development Southern Africa, 17, 201-219. https://doi.org/10.1080/713661400

Peberdy, S. (2007). Monitoring small scale cross border trade in Southern Africa. A Report for the Regional Trade Facilitation Programme, Southern African Migration Project, Johannesburg.

Rogerson, C.M. (2014a). Viewpoint: How pro-poor is business tourism in the global South? International Development Planning Review, 36(4), 5-15. https://doi.org/10.3828/idpr.2014.29

Rogerson, C.M. (2014b). The uneven geography of business tourism in South Africa. African Journal of Hospitality, Tourism and Leisure, 3(1), 1-15. https://doi.org/10.1080/03736245.2015.1028984

Rogerson, C.M. (2015). Unpacking business tourism mobilities in sub-Saharan Africa. Current Issues in Tourism, 18(1), 44-56. https://doi.org/10.1080/13683500.2014.898619

Rogerson, C.M. (2018). Informal sector city tourism: Cross-border shoppers in Johannesburg. GeoJournal of Tourism and Geosites, 22(2), 381-392. https://doi.org/10.30892/gtg.22209-296

Rogerson, C.M., \& Letsie, T. (2013). Informal sector business tourism in the global South: Evidence from Maseru, Lesotho. Urban Forum, 24, 485-502. https://doi.org/10.1007/s12132-013-9196-y

Scheyvens, R. (2007). Poor cousins no more: Valuing the development potential of domestic and diaspora tourism. Progress in Development Studies, 7, 307-325. https://doi.org/10.1177/146499340700700403

Spencer, J.P., \& Bavuma, A. (2018). How important are MICE to the tourism economy? 8th International Conference on Restructuring of the Global Economy, University of Oxford, UK. 9-10 July.

Sylla, M., Chruscinski, J., Druzynska, P., Plociennik, P., \& Osak, W. (2015). Opportunities and limitations for mice tourism development in Łódź. Tourism, 25(2), 117-124. https://doi.org/10.1515/tour-2015-0011

Tichaawa, T.M. (2017). Business Tourism in Africa: The case of Cameroon. Tourism Review International, 22, 181-192. https://doi.org/10.3727/154427217X14939227920829

Tichaawa, T.M., \& Kimbu, A.N. (2019). Unlocking policy impediments for service delivery in tourism firms: Evidence from small and medium sized hotels in Sub-Saharan Africa. Tourism Planning \& Development, 16(2), 179-196. https://doi.org/10.1080/21568316.2018.1556328

Timothy, D., \& Teye, V.B. (2005). Informal sector business travelers in the developing world: A borderlands perspective. The Journal of Tourism Studies, 16, 82-92. https:// doi.org/10.3316/ielapa.200509022

Van Eeden, A. (2011). The geography of informal arts and crafts traders in South Africa's four main city centres. Town and Regional Planning, 59, 34-40.

*** International Organisation for Migration (IOM). (2010). Informal Cross-border Trade: Regional Assessment on HIV-Prevention Needs of Migrants and Mobile Populations in Southern Africa, Washington, D.C, USAid.

*** Organisation for Economic Co-operation and Development (OECD). (2019). Tackling vulnerability in the informal economy. Development Centre Studies. OECD Publishing, Paris.

*** United Nations Conference on Trade and Development (UNCTAD) (2019). Borderline: Women in informal cross-border trade in Malawi, the United Republic of Tanzania and Zambia, United Nations, Geneva.

*** United Nations World Tourism Organisation (UNWTO). (2017). Tourism Highlights, UNWTO: Geneva.

*** World Bank (2012). Transformation through tourism: Development dynamics past, present and future, The World Bank, Washington DC.

*** World Travel and Tourism Council (WTTC). (2019). Tourism Economic Impact, WTTC, World. London. 